\title{
Appraisal of Super-Fast Membrane Bioreactors by MASM-A New Activated Sludge Model for Membrane Filtration
}

\author{
Derin Orhon $^{1}$, Ayse Begum Yucel ${ }^{2}$, Güçlü Insel ${ }^{2}$, Bülent Solmaz ${ }^{3}$, Raif Mermutlu ${ }^{3}$ and Seval Sözen ${ }^{2,4, *(D)}$ \\ 1 The Science Academy, Istanbul 34349, Turkey; orhon@itu.edu.tr \\ 2 Environmental Engineering Department, Faculty of Civil Engineering, Istanbul Technical University, \\ Istanbul 34469, Turkey; aysebegumyucel@gmail.com (A.B.Y.); inselhay@itu.edu.tr (G.I.) \\ 3 Istanbul Water and Sewerage Administration, Istanbul 34060, Turkey; bsolmaz@iski.gov.tr (B.S.); \\ raifmermutlu@iski.istanbul (R.M.) \\ 4 ENVIS Energy and Environmental Systems Research and Development Ltd., ITU ARI Technocity, \\ Istanbul 34469, Turkey \\ * Correspondence: sozens@itu.edu.tr; Tel.: +90-212-286-0303; Fax: +90-212-285-6587
}

Citation: Orhon, D.; Yucel, A.B.; Insel, G.; Solmaz, B.; Mermutlu, R.; Sözen, S. Appraisal of Super-Fast Membrane Bioreactors by MASMA New Activated Sludge Model for Membrane Filtration. Water 2021, 13, 1963. https://doi.org/10.3390/ w13141963

Academic Editor: Jaime Lora Garcia

Received: 5 June 2021

Accepted: 11 July 2021

Published: 17 July 2021

Publisher's Note: MDPI stays neutral with regard to jurisdictional claims in published maps and institutional affiliations.

Copyright: (c) 2021 by the authors. Licensee MDPI, Basel, Switzerland. This article is an open access article distributed under the terms and conditions of the Creative Commons Attribution (CC BY) license (https:// creativecommons.org/licenses/by/ $4.0 /)$.

\begin{abstract}
The structure of existing activated models is inherently deficient in reflecting the major role of the membrane filtration. The study developed a novel model, MASM, for the membrane activated process. The effective filtration size imposed by the membrane module, entrapping larger particles, was adopted as the basis of the proposed model. The model defines a modified form of COD fractionation that accounts for the captured COD fractions as additional model components and utilizes related mass-balance relationships. It was implemented to test the fate of soluble hydrolyzable COD and the system performance of super-fast membrane activated sludge based on real data for the characterization and process kinetics of domestic sewage and denim processing effluents. Model evaluation was carried out for parallel systems with gravity settling and membrane filtration operated at a sludge age range of $0.5-2.0 \mathrm{~d}$. Results reflected significantly better performance by the superfast membrane activated sludge system for both wastewaters, underlining that it was crucially important to account for the captured COD fractions to provide an accurate evaluation of system behavior and effluent quality. This should also be identified as the major shortcoming of the ASM models for evaluating and predicting the system performance of activated sludge configurations with membrane separation.
\end{abstract}

Keywords: MASM; new model for membrane activated sludge system; super-fast membrane activated sludge; particle size distribution; modified COD fractionation; captured COD fractions

\section{Introduction}

Membrane filtration of biomass should be recognized as a cutting-edge landmark that would perhaps reshape the future of the activated sludge process. It took over the function of gravity settling, which accompanied the process since its discovery [1]. Gravity settling has always been the weak spot in the process, mainly because it could not cope with excessive biomass escape under conditions of filamentous bulking; it imposed limitations restricting biomass concentration in the reactor; and most importantly, it distorted system design, as the main concern had to be sustaining good settling conditions for biomass based on empirical experience, often leading to higher footprints [2]. The membrane bioreactor, (MBR), with a membrane module replacing the gravity settling tank, liberates the system from all constraints simply by uncoupling the hydraulic retention time (HRT) and the sludge age (SRT), leading to a much smaller footprint.

While it was originally conceived for the activated sludge process, the "bioreactor" part of the MBR system was greatly diversified in recent years, as a result of the creativity and inspiration of massive experimental studies: nowadays, moving bed MBRs, membrane adsorption reactors, membrane coagulation reactors, vertical submerged MBRs, 
submerged rotating MBRs, Anammox MBRs, anaerobic MBRs, etc., have been proposed as MBR systems with different biological reactor alternatives [3-8]. It seems now that the term MBR has become quite ambiguous, since it does not specify the bioreactor configuration accompanying the membrane module. Therefore, an activated sludge configuration with a membrane module should be differentiated from other alternatives as membrane activated sludge (MAS). Furthermore, development of these process modifications was largely based on empirical experience. While such techniques, coupled with common sense and ingenuity, were successful for the specific cases in which they were utilized, they still required a rational mechanistic description to provide a reliable basis for evaluation.

The MAS system enabled total entrapment and control of biomass in the reactor. This ability was initially utilized for system operation for far greater sludge ages with equally high biomass concentrations in the range of 10.000-50.000 mg/L [9]. This type of MAS system with extended aeration was mostly tested for effective nitrogen removal $[10,11]$. Later, it was soon recognized that MAS also offered a stable system operation at far lower SRT values as excessively high-rate systems. The concept of high-rate activated sludge first emerged in the forties, based on accidental observations of high BOD removal rates, even when the aeration time was reduced to $2.0 \mathrm{~h}$ [12]; however, its implementation did not prove satisfactory during that period, mostly due to sludge settling problems. The advent of MAS revived this concept: initial studies with MAS systems sustained at a SRT range of 0.25 to 5.0 days, and reported COD removal efficiencies above $95 \%$ with stable system operation $[13,14]$. Later, numerous studies conducted with different substrates, such as readily biodegradable mixtures, acetate, starch, peptone mixture and settled sewage, indicated that complete removal of biodegradable substrate could be achieved until 2.0 days passed [15-17]. They essentially proved that operation at high SRT values was simply a useless luxury for MAS systems.

Evolution of activated sludge modeling (ASMs) served as a tremendous asset for exploring and interpreting the waste array of biochemical mechanisms taking place in the mixed culture; for the adoption of COD as the major parameter for all substrate and biomass components; for the identification of COD fractions with different biodegradation characteristics; and for respirometry, which was thereby enabled to harness and control the composition of the microbial community to perform the required metabolic functions with the use of relevant models [18-20]. However, existing models simply overlooked the size distribution of substrate and involved only a single size threshold of $450 \mathrm{~nm}$ for differentiating "particulate" and "soluble" fractions. The distinction between these fractions should be considered in different model structures. This modeling approach, while quite successful for conventional activated sludge configurations with gravity settling, is obsolete for MAS systems simply because the applicable size threshold lowers to the effective filtration size of the selected membrane. This is a drastic change that would affect applicable COD fractionation, mass balance and model structure. It also underlines the need to reshape ASMs because they would greatly distort and undervalue the behavior and performances of MAS systems.

In this context, the main objective of the study was to define a new model, MASM, for membrane activated sludge configurations based on modified COD fractionation and a modified particle size distribution. The objective of the study also involved providing an accurate image of the microbial processes taking place in super-fast membrane activated sludge systems (SFMAS) during organic carbon removal, through the implementation of the new model for domestic sewage and textile wastewater.

\section{Materials and Methods}

\subsection{Conceptual Approach}

The effect of the membrane module on activated sludge modelling can best be recognized with a full understanding of the relevant experimental tools. These tools are currently used to understand the complex nature of organics (COD) in wastewaters and to assess model components and process kinetics used in the model structure; they mainly 
involve respirometric analysis, COD fractionation and particle size distribution, all leading to accurate mass balancing of significant model components.

\subsubsection{COD Fractionation}

The key feature of COD fractionation is the possibility that each fraction may be interpreted with a specific process kinetics when introduced into ASM models. The assessment of specific kinetics by respirometric techniques should perhaps be regarded as one of the major achievements toward understanding substrate behavior in biological systems [21].

Nowadays, the observation of the oxygen uptake rate profile (OUR) serves as the specific fingerprint of the wastewater for identifying its COD fractions and the coefficients of the process kinetics involved [22]. Direct experimental methods based on COD balance also enable one to quantify inert COD fractions and residual metabolic products $[23,24]$. This way, ASMs are now structured to include four "soluble" COD components below the size threshold of $450 \mathrm{~nm}$, which could be differentiated with different biodegradation characteristics: they are identified as readily biodegradable COD, $\mathrm{S}_{\mathrm{S}}$; soluble hydrolyzable $\mathrm{COD}, \mathrm{S}_{\mathrm{H}}$; initial inert $\mathrm{COD}, \mathrm{S}_{\mathrm{I}}$, and residual soluble microbial products, $\mathrm{S}_{\mathrm{P}}$. The first three COD fractions essentially define the COD content of the influent wastewater stream, and the fourth, $S_{\mathrm{P}}$, is generated as part of the biochemical reactions in the reactor. $\mathrm{S}_{\mathrm{H}}$ was incorporated later into ASMs, in view of the significant differences in the rate of hydrolysis when compared with that of its particulate counterpart, the slowly biodegradable COD, $\mathrm{X}_{\mathrm{S}}[25,26]$.

\subsubsection{Particle Size Distribution}

For organic matter, there are obvious relationships among biodegradation properties and particle size. Existing activated sludge models provide good understanding of biodegradation by means of COD fractionation, but largely overlook the significance of particle size distribution, PSD. Recently, the concept of PSD was revived and used for exploring major parameters such as COD, total organic carbon (TOC), color, protein and carbohydrates by means of a new procedure involving sequential filtration/ultrafiltration from $1600 \mathrm{~nm}$ all the way down to $2 \mathrm{~nm}$. This procedure offers a specific size fingerprint of the selected parameter and has been widely applied for domestic sewage and different industrial wastewaters [27-31]. Lately, a few pioneering studies implemented PSD analysis together with oxygen uptake rate measurements, in order to couple particle size with COD fractionation [32-34]. In this context, the experimental work was particularly significant, as it revealed a new aspect related to the fate of $S_{H}$ in biological treatment: The PSD analysis of the influent stream indicated a small fraction of $5 \mathrm{mg} / \mathrm{L}$ in the $220-450 \mathrm{~nm}$ size bracket. After biological treatment, $S_{\mathrm{H}}$ was observed to increase to $20 \mathrm{mg} / \mathrm{L}$ in the same size range. This finding could only be explained by sequential hydrolysis of a fraction of slowly biodegradable particulate $\mathrm{COD}, \mathrm{X}_{\mathrm{S}}$, into $\mathrm{S}_{\mathrm{H}}$.

\subsection{Model Structure}

This study was essentially designed to address the following questions: "Is a new model needed for assessing the fate of organic carbon (COD) in membrane activated sludge systems? If so, why?" It is unfortunate to note that related studies mostly avoided those questions, because they remained limited to empirical observations. This section confirms and justifies this need by uncovering radical changes imposed on major modeling concepts by replacing gravity settling with membrane filtration in the activated sludge process:

A brief preamble, membrane activated sludge process (MAS) device is one that provides retention and recycling of biomass, just like the gravity settling unit in the conventional activated sludge process (CAS). The gravity settling unit is conceived as a unit that retains all particles with a size greater than $450 \mathrm{~nm}$, whereas the retention threshold of the membrane module is much lower and it goes even lower than the nominal pore size of the membrane filter due to cake layer formation. This change in the applicable 
size threshold reflects the modeling as a radical change in the selection of new model components-i.e., COD fractionation in the case of organic carbon removal. In CAS modeling, particulate and "soluble" compounds are differentiated by the arbitrary size threshold of $450 \mathrm{~nm}$, which also defines biomass; however, MAS modeling should account for and adopt as additional model components entrapped fractions of a number of COD fractions, namely, $S_{H}, S_{I}$ and $S_{P}$, because these entrapped fractions will all be subject to different mass balances controlled by sludge age.

\subsubsection{Effective Filtration Size}

At this point it is important to revisit the implication of $450 \mathrm{~nm}$, the sole size threshold incorporated in existing ASMs. First, it is the filtration size to define suspended solids/biomass in wastewaters and biological reactors. This way, it is used to differentiate particulate fractions that can be sustained in the reactor from soluble fractions of the treated wastewater escaping the system through the effluent stream. Therefore, soluble COD covers a wide range of particle sizes below $450 \mathrm{~nm}$. Existing ASMs define the total effluent soluble $\mathrm{COD}, \mathrm{S}_{\mathrm{TE}}$, in terms of the remaining portion of the soluble hydrolyzable $\mathrm{COD}, \mathrm{S}_{\mathrm{HE}}$, after biodegradation; the initial soluble inert $\mathrm{COD}, \mathrm{S}_{\mathrm{I}}$; and residual soluble microbial products, $S_{P}$. The readily biodegradable COD, $S_{S}$, would be most likely completely depleted and not detected in the effluent.

Membrane filtration completely changes this basic framework: First of all, the size threshold of $450 \mathrm{~nm}$ is made totally obsolete, as the pore sizes of membranes used in MAS systems are usually in the ultrafiltration range and far smaller than $450 \mathrm{~nm}$, offering a far greater capture potential for soluble COD fractions. Furthermore, in an MAS reactor, an effective filtration size would be created through the operation of the system at a level lower than the actual pore size of the membrane unit, due to additional cake filtration effect induced by biofilm formation on the surface of the membrane [33,35]. Formation of a dynamic cake layer at the membrane surface is generally attributed to the gradual accumulation of recalcitrant organic matter, generated in the course of biochemical reactions in the activated sludge reactor. This matter was mostly identified as soluble microbial products (SMPs), which remain solid, at least under the operational conditions of the system [36]. SMPs were detected in a wide size range of $<0.550 \mathrm{kDa}$ in the effluents of many biological treatment plants [37]. Observations indicated that SMP deposition on the membrane surface often played a beneficial role in bringing down the effective filtration size, to entrap organic matter that would otherwise pass through the membrane pore [38]. This layer would also behave as an auxiliary membrane, preventing smaller foulant particles from reaching the membrane's surface [39].

The effect of biofilm formation on the effective filtration size was observed in many cases: In a study which investigated the kinetics of acetate utilization via superfast membrane reactor (SFMBR), the effective filtration size was reduced to approximately 8-13 $\mathrm{nm}$ from the nominal filter size of $20 \mathrm{~nm}$; the system completely removed acetate, and generated $S_{P}$ exhibiting a bi-modal distribution of $>13 \mathrm{~nm}$ and $<2 \mathrm{~nm}$. In total, $12-17 \mathrm{mg} / \mathrm{L}$ of $\mathrm{S}_{\mathrm{P}}$ was lost in the effluent, and the remaining 1-2 $\mathrm{mg} / \mathrm{L}$ was entrapped by the membrane and accumulated in the reactor $[15,16]$. The entrapped fraction of $S_{P}$ exhibited a slight increase from $1-2$ to 3-6 $\mathrm{mg} / \mathrm{L}$ with more hydraulic retention time in a slightly earlier SFMBR study, conducted on the same system fed with a readily biodegradable COD mixture [40]. Sözen et al. [17] investigated the energy conservation potential of SFMBR equipped with a $40 \mathrm{~nm}$ ultrafiltration membrane using settled sewage. They also observed the same range of 8-13 nm for the effective filtration size. Permeate COD levels were measured as 42, 35 and $33 \mathrm{mg} / \mathrm{L}$, all including $18 \mathrm{mg} / \mathrm{L}$ of initial inert COD, $\mathrm{S}_{\mathrm{I}}$, for sludge ages of 0.5, 1.0 and $2.0 \mathrm{~d}$, respectively; entrapped COD remained in the range of $3.3-4.8 \mathrm{mg} / \mathrm{L}$. In another study on the biodegradation kinetics of black and grey fractions in segregated domestic sewage, effective filtration size was observed to be in the range of 8-14 $\mathrm{nm}$ for black water and 5-8 nm for grey water, regardless of the fact that the MBR used for the study included a membrane with a nominal filter size of $400 \mathrm{~nm}$ [33]. 
In this context, the membrane module coupled to an activated sludge configuration induces a radical change for the size threshold of $450 \mathrm{~nm}$ implemented for differentiating COD fractions, bringing it down to the effective filtration size, which was determined to be $8-13 \mathrm{~nm}$ in related experimental studies.

\subsubsection{Modified COD Fractionation and Mass Balance}

COD fractionation is well reported in the literature: it identifies COD fractions with different biodegradation characteristics in wastewaters. Related experimental assessments rely on model calibration of the oxygen uptake rate profiles (OUR) obtained for the selected wastewater [41]. Direct methods also supplement respirometry for the determination of inert COD fractions and residual microbial products $[23,24]$. This way, ASMs are now structured to include four "soluble" COD components below the size threshold of $450 \mathrm{~nm}-$ namely, readily biodegradable COD, $\mathrm{S}_{\mathrm{S}}$; soluble hydrolyzable $\mathrm{COD}, \mathrm{S}_{\mathrm{H}}$; initial inert COD, $\mathrm{S}_{\mathrm{I}}$; and soluble residual microbial products, $\mathrm{S}_{\mathrm{P}}$. The first three COD fractions essentially define the COD content of the influent wastewater stream, and the fourth, $\mathrm{S}_{\mathrm{P}}$, is generated through the biochemical reactions in the reactor. $\mathrm{S}_{\mathrm{H}}$ was incorporated later into ASMs, in view of the significant difference in the rate of hydrolysis when compared with its particulate counterpart, the slowly biodegradable COD, $X_{S}[25,26]$. In addition to $X_{S}, A S M s$ also include active biomass, $\mathrm{X}_{\mathrm{H}}$; initial inert particulate $\mathrm{COD}, \mathrm{X}_{\mathrm{I}}$; and particulate residual metabolic products, $\mathrm{X}_{\mathrm{P}}$, as particulate components.

Membrane separation in MAS systems induces a major change in the soluble range $\left(>450 \mathrm{~nm}\right.$ ) of COD fractionation, where the soluble hydrolyzable COD, $\mathrm{S}_{\mathrm{H}}$, is usually the major COD fraction. The decrease of the traditional size threshold of $450 \mathrm{~nm}$ down to the effective filtration size imposes a compulsory subdivision of $S_{H}$ into two new COD fractions: $\mathrm{S}_{\mathrm{HC}}$, which will be entrapped by the membrane and captured in the reactor, and $\mathrm{S}_{\mathrm{H}}$, the portion with contents smaller in size than the effective filtration size. The remaining part of $S_{\mathrm{H}}$ after the hydrolysis reaction in the reactor, $\mathrm{S}_{\mathrm{HE}}$, will bypass the membrane module with the effluent. Similarly, the soluble inert COD, $\mathrm{S}_{\mathrm{I}}$, will be split into $\mathrm{S}_{\mathrm{IC}}$ and $\mathrm{S}_{\mathrm{I}}$ fractions. The readily biodegradable $\mathrm{COD}, \mathrm{S}_{\mathrm{S}}$, will not be affected by the effective filtration size because it is located at the far end of the size spectrum. Figure 1 shows a schematic display of the new COD fractionation as modified by the membrane module together with the one associated with the AS system with gravity settling. It is clear that the modified COD fractionation reflects a different biodegradation fingerprint of the wastewater, which would significantly improve the system's performance.

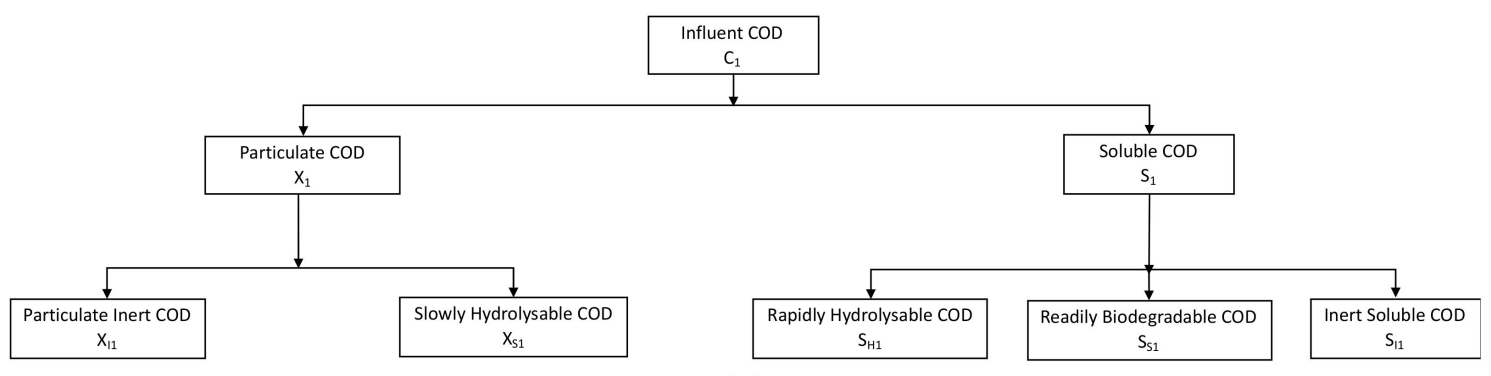

(a)

Figure 1. Cont. 


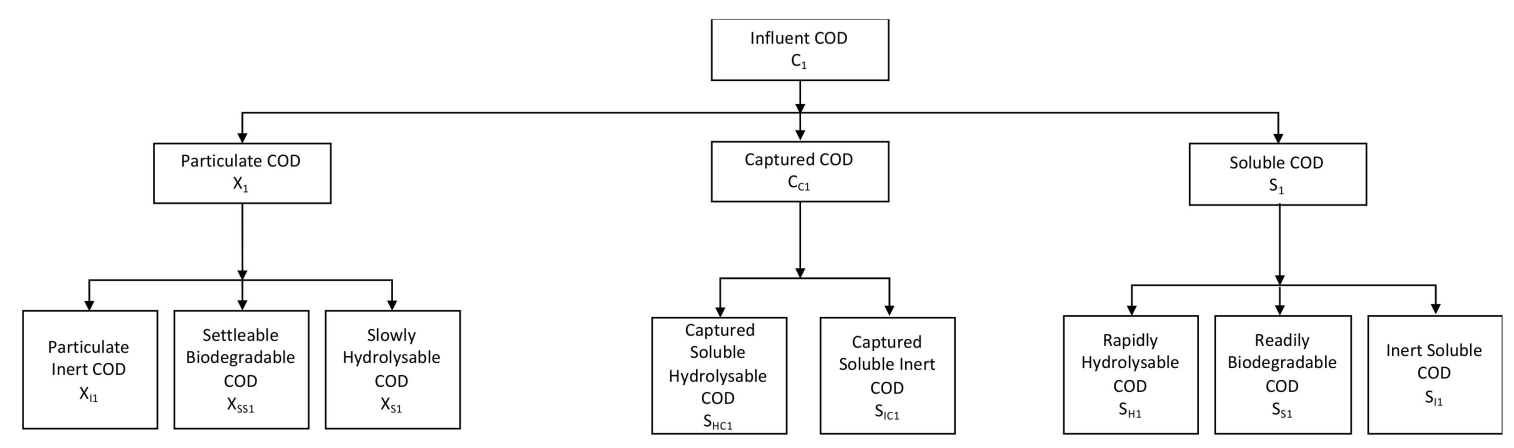

(b)

Figure 1. Schematic display of COD fractionation (a) associated with ASMs (b) modified for MASM.

Obviously, $\mathrm{S}_{\mathrm{HC}}$ and $\mathrm{S}_{\mathrm{H}}$ will be subject to the same reaction kinetics for hydrolysis. However, MAS systems impose totally different mass balances for these two fractions, which has a significant impact on process performance. The fate of $\mathrm{S}_{\mathrm{HC}}$ accumulated in the reactor should be defined by the following mass-balance equation:

$$
\mathrm{QS}_{\mathrm{HC} 1}-\mathrm{P}_{\mathrm{SHC}}+\mathrm{V}_{\mathrm{SHC}}=0
$$

where, $\mathrm{P}_{\mathrm{SHC}}$ is $\mathrm{S}_{\mathrm{HC}}$ discharged with excess sludge, and $\mathrm{r}_{\mathrm{SHC}}$ is the rate expression for hydrolysis.

This equation clearly explains why the behavior of $S_{\mathrm{HC}}$ that remains in the reactor will be just like slowly biodegradable particulate matter, $\mathrm{X}_{\mathrm{S}}$. Therefore, $\mathrm{S}_{\mathrm{HC}}$ basically becomes a part of sludge and $\mathrm{P}_{\mathrm{SHC}}$ can be expressed as:

$$
\mathrm{P}_{\mathrm{SHC}}=\frac{\mathrm{V} \mathrm{S}_{\mathrm{HC}}}{\mathrm{SRT}}
$$

Equations (2) and (3) provide clear indication that $\mathrm{S}_{\mathrm{HC}}$ is controlled in the reactor by the sludge age. A similar differentiation is applicable and necessary for soluble residual COD fractions, $S_{I}$ and $S_{P}$, in terms of prediction of system performance.

Similarly, the following mass-balance equation defines the fate of $S_{H}$ that would escape the system with the effluent stream:

$$
\mathrm{QS}_{\mathrm{H} 1}-\mathrm{QS}_{\mathrm{HE}}+\mathrm{Vr}_{\mathrm{SH}}=0
$$

This equation applies to all activated sludge configurations, and clearly shows that the magnitude of $\mathrm{S}_{\mathrm{HE}}$ is controlled by the hydraulic retention time, HRT, selected for system operation.

\subsubsection{Model Description}

The basic concepts summarized above were used to define the structure of the new model, MASM, applicable to membrane activated sludge configurations. The model's structure essentially involves the template of ASM1 for organic carbon removal, modified for endogenous decay $[40,42]$. Obviously, it reflects a modified COD fractionation, which also accounts for $\mathrm{S}_{\mathrm{HC}}$ and $\mathrm{S}_{\mathrm{IC}}$ as model components. As can be visualized in Table 1, which gives the usual matrix format, MASM includes the modified COD fractions, namely, $\mathrm{S}_{\mathrm{IC}}$; $\mathrm{S}_{\mathrm{I}}, \mathrm{S}_{\mathrm{SS}}, \mathrm{S}_{\mathrm{HC}}, \mathrm{S}_{\mathrm{H}}, \mathrm{X}_{\mathrm{I}}$ and $\mathrm{X}_{\mathrm{S}}$, in the wastewater as model components. Soluble and particulate residual microbial products, $S_{P}$ and $X_{P}$, were also defined in terms of endogenous respiration with the simplifying assumption of a decay-associated generation process [36]. Obviously, the model template also includes active heterotrophic biomass concentration, $\mathrm{X}_{\mathrm{H}}$, and finally, dissolved oxygen concentration. These are the basic parameters for the evaluation of the OUR profiles. 
Table 1. Matrix representation of the new model for membrane activated sludge.

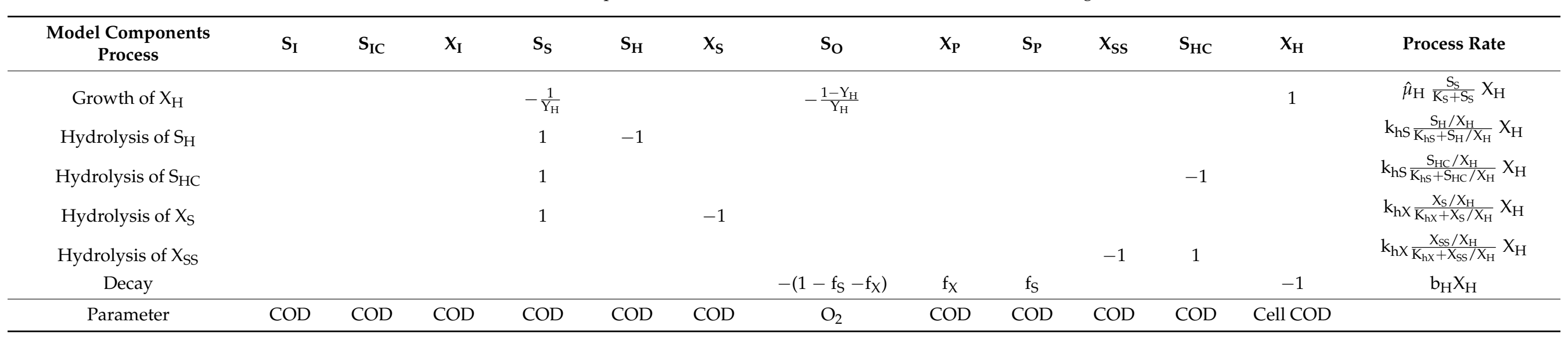


Moreover, in the light of reported PSD analyses [43], the model also adopted a similar differentiation for the overall particulate slowly biodegradable COD fraction, differentiating the settleable fraction, $X_{\mathrm{SS}}$, from the remaining part, $\mathrm{X}_{\mathrm{S}}$, which both undergo hydrolysis: while the hydrolysis of $X_{S}$ would directly generate $S_{S}$, as assumed in the ASMs, the hydrolysis of $X_{S S}$ is defined as following a two-step reaction with initial hydrolysis and conversion into $\mathrm{S}_{\mathrm{HC}}$. Settleable inert COD, $\mathrm{X}_{\mathrm{IS} 1}$, is considered as a part of the particulate inert COD, $\mathrm{X}_{\mathrm{I}}$, in the model.

At this point, it is crucially important to remember that from the pioneering work on modelling by Garret and Sawyer [44], to the ASM series, i.e., ASM1, ASM2, ASM2d, ASM3, etc., all AS models have been biological/biochemical models in nature. They have been also called "biokinetic" models defining mathematical interactions between substrate and the microbial culture/biomass. Thus, their structure, as in Table 1, only included model components, processes, process rates, process coefficients and the stoichiometry between processes. They started from two-process (microbial growth/endogenous respiration) and two-component (substrate/biomass) models and expanded into the current multicomponent/multi-process models.

Consequently, AS models do not include hydraulic characteristics such as average hydraulic residence time, reactor hydraulics and residence time distributions. These characteristics are only incorporated to the selected model for specific cases, i.e., case studies, where the hydraulic configurations of the reactor systems and those of the membrane modules are well defined. Therefore, the concept of validation is obsolete for activated sludge models, because they can only be used for calibration with experimental data generated from the wastewater to be treated, i.e., oxygen uptake rate (OUR) profiles, etc., to yield applicable COD fractionation and/or kinetic and stoichiometric coefficients that would be used in model evaluation [45].

It should be noted that model simulations for assessing system performance rely on mass balances established on the basis of process kinetics and reactor hydraulics. Process kinetics are provided by the adopted model calibrated for the selected wastewater. However, reactor hydraulics cannot be properly defined by the hydraulic retention time $(\mathrm{SRT}=\mathrm{V} / \mathrm{Q})$, which only gives an average value of the residence time distribution of fluid particles involved in the real-size reactor. Generally, a completely mixed (CSTR) is used to simulate reactor hydraulics in mass balance. CSTR is an ideal reactor simulating extreme mixing conditions, just like a plug-flow reactor with no longitudinal mixing. Real biological reactors can only be placed between these two extremes. Thus, an accurate account of the residence time distribution in the biological reactor can only be obtained by using 3-4 CSTRs in series [46].

In this study, the activated sludge configuration for modeling was created by SUMO [47]. The configuration involved three CSTRs that were linked to each other, and at the end of the process, a point separator acting as a membrane module. From the point separator, the return activated sludge was linked to the first CSTR compartment, and the waste activated sludge was separated for dewatering. The flowrate of the system defined as $10000 \mathrm{~m}^{3} / \mathrm{d}$, and the magnitude of recycled activated sludge flow rate (RAS) remained variable for different runs. Figure 2 displays the process configuration used in modeling.

The simulation using the proposed model was carried out by means of SUMO software. SUMO is a processor wherein related mathematical calculations are reflected with $100 \%$ accuracy. Before the simulation, the model was calibrated with the oxygen uptake rate (OUR) profiles generated with the selected wastewater. In previous studies, the standard deviation of the OUR measurements was assessed as 3\%, a level, which is the same as that of COD analysis [48]. 


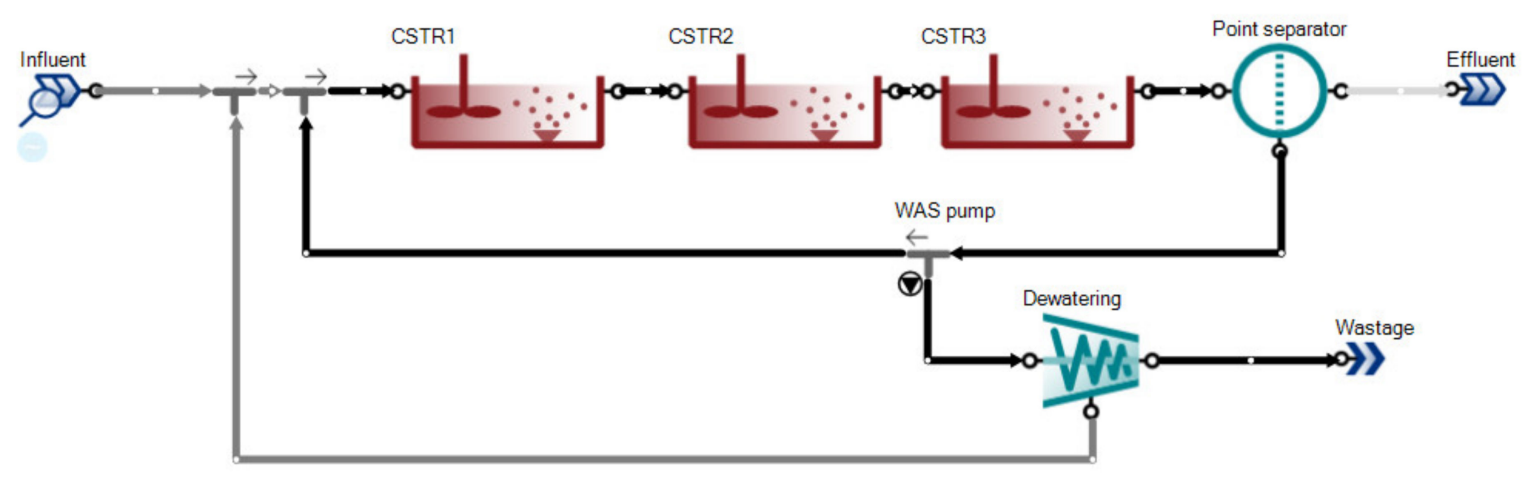

Figure 2. The SUMO configuration used in modeling.

\subsection{Model Components and Process Kinetics}

Modified COD fractionation associated with domestic sewage and textile wastewater was defined based on reported data in studies, which conducted parallel experimental work on assessments of COD fractions by respirometry coupled with PSD analysis [28,43]. Modified COD fractions were also incorporated into the model structure as model components. This approach was a prerequisite for providing accurate and reliable information concerning the fractions for soluble COD components that would be entrapped and captured in the reactor by means of membrane filtration. The modified COD fractionations characterizing selected wastewaters are given listed in Table 2.

Table 2. Modified COD fractionation for domestic sewage and textile wastewater.

\begin{tabular}{|c|c|c|}
\hline $\begin{array}{l}\text { Wastewaters } \\
\text { Parameters }\end{array}$ & Domestic [43] & Textile [28] \\
\hline Total COD (mg/L), $\mathrm{S}_{1}+\mathrm{X}_{1}$ & 415 & 1340 \\
\hline Total Soluble COD (mg/L), $\mathrm{S}_{1}$ & 120 & 965 \\
\hline Total Particulate COD (mg/L), $X_{1}$ & 295 & 375 \\
\hline Readily Biodegradable COD (mg/L), $\mathrm{S}_{\mathrm{S} 1}$ & 40 & 280 \\
\hline Total Soluble Hydrolyzable COD $(\mathrm{mg} / \mathrm{L}), \mathrm{S}_{\mathrm{H} 1}+\mathrm{S}_{\mathrm{HC} 1}$ & 62 & 460 \\
\hline Influent Soluble Hydrolyzable COD (mg/L), $\mathrm{S}_{\mathrm{H} 1}$ & 15 & 100 \\
\hline Captured Soluble Hydrolyzable COD (mg/L), $\mathrm{S}_{\mathrm{HC} 1}$ & 47 & 360 \\
\hline Total Soluble Inert COD $(\mathrm{mg} / \mathrm{L}), \mathrm{S}_{\mathrm{I} 1}+\mathrm{S}_{\mathrm{IC} 1}$ & 18 & 225 \\
\hline Influent Soluble Inert COD (mg/L), $\mathrm{S}_{\mathrm{I} 1}$ & 10 & 135 \\
\hline Captured Soluble Inert COD (mg/L), S & 8 & 90 \\
\hline Total Particulate Hydrolyzable COD (mg/L), $\mathrm{X}_{\mathrm{S} 1}+\mathrm{X}_{\mathrm{SS} 1}$ & 253 & 360 \\
\hline Influent Particulate Hydrolyzable COD (mg/L), $X_{\mathrm{S} 1}$ & 113 & 162 \\
\hline Settleable Biodegradable COD (mg/L), $\mathrm{X}_{\mathrm{SS} 1}$ & 140 & 198 \\
\hline Total Particulate Inert COD $(\mathrm{mg} / \mathrm{L}), \mathrm{X}_{\mathrm{I} 1}+\mathrm{X}_{\mathrm{IS} 1}$ & 42 & 15 \\
\hline Influent Particulate Inert COD (mg/L), $\mathrm{X}_{\mathrm{I} 1}$ & 19 & 7 \\
\hline Settleable Inert COD (mg/L), $\mathrm{X}_{\mathrm{IS} 1}$ & 23 & 8 \\
\hline
\end{tabular}

A detailed literature survey was carried out for the kinetic coefficients defining process kinetics for the selected wastewaters. Values adopted for model evaluation generally approximated the average levels indicated by the experimental data suggested in the literature for each type of wastewater, as listed in Table 3. It should be noted that the textile industry embraces various categories based on fabrics and processes involved, each generating a specific type of wastewater, quite different from one another. In this context, kinetic coefficients defining denim processing were adopted, since the characterization and particle size distribution given in Table 2 also relate to that textile category. The heterotrophic yield coefficient, $\mathrm{Y}_{\mathrm{H}}$, was adopted as $0.64 \mathrm{mg}$ cell COD/mg COD for domestic sewage and $0.69 \mathrm{mg}$ cell COD/mg COD for textile wastewater. Soluble and particulate residues of endogenous respiration, $f_{S}$ and $f_{X}$, were selected as 0.05 and 0.10 , respectively $[49,50]$. 
Table 3. Selected values of kinetic coefficients for different wastewaters.

\begin{tabular}{ccccccccc}
\hline Wastewater Type & \multicolumn{8}{c}{ Dual Hydrolysis } \\
\hline & $\hat{\mu}_{\mathbf{H}}$ & $\mathbf{K}_{\mathbf{S}}$ & $\mathbf{b}_{\mathbf{H}}$ & $\mathbf{k}_{\mathbf{h S}}$ & $\mathbf{K}_{\mathbf{h S}}$ & $\mathbf{k}_{\mathbf{h X}}$ & $\mathbf{K}_{\mathbf{h x}}$ & References \\
\hline Domestic & & & & & & & & \\
& 3.5 & 3 & 0.2 & 3.5 & 0.12 & 1.7 & 0.2 & {$[51]$} \\
& 4.2 & 3 & - & 1.6 & 0.07 & 0.8 & 0.04 & {$[52]$} \\
& 3.5 & 6 & 0.2 & 3.8 & 0.2 & 1.9 & 0.18 & {$[53]$} \\
& 4 & 4 & 0.18 & 2.8 & 0.03 & 1.1 & 0.1 & {$[54]$} \\
Selected for Model & - & - & 0.24 & 3.1 & 0.2 & 1.2 & 0.5 & {$[55]$} \\
Textile & 4.2 & 3 & 0.2 & 2.96 & 0.12 & 1.34 & 0.20 & \\
& & & & & & & & \\
& - & - & - & 2.5 & 0.4 & 0.1 & 0.5 & {$[55]$} \\
& 4.1 & 5 & 0.18 & 3 & 0.05 & 1 & 0.5 & {$[56]$} \\
& 5.3 & 5 & 0.14 & 3 & 0.05 & 1 & 0.2 & {$[56]$} \\
Selected for Model & 3.6 & 15 & 0.14 & 0.8 & 0.05 & 0.5 & 0.15 & {$[56]$} \\
& 6 & 1 & 0.1 & 3.5 & 0.04 & 0.72 & 0.04 & {$[57]$} \\
& 3.6 & 15 & 0.14 & 2.45 & 0.09 & 0.68 & 0.28 & \\
\hline
\end{tabular}

In this context, the values reported in Tables 2 and 3 essentially reflect the calibration of the proposed model, MASM, using the real data collected from the literature, since they were derived from the experimental characterizations of the selected wastewaters.

\section{Modeling Results and Discussion}

\subsection{Basis for Evaluation}

It should be noted that the simulation exercise relied on already existing experimental data in the literature, to increase the credibility of the study, and mainly, to show that all necessary clues to underline the need for a new activated sludge model for MAS systems already existed. In this context, the research methodology for similar studies should involve: (i) respirometric analysis and direct methods for identifying the six major COD fractions, namely, $X_{I}, X_{S S}, X_{S}, S_{H}, S_{S}$ and $S_{I}$, thereby providing the intrinsic biodegradation fingerprint of the wastewater $[23,24]$. (ii) Particle size distribution analysis for COD components in the wastewater [28]. (iii) Assessment of the effective filtration size for identification of captured COD fractions ( $\mathrm{S}_{\mathrm{HC}}$ and $\mathrm{S}_{\mathrm{IC}}$ ), as described in detail in [58].

Two wastewaters were selected for model evaluation, domestic sewage and textile (denim processing) effluents. Aside from the fact that the selected textile wastewater was much stronger, with a total COD content of $1340 \mathrm{mg} / \mathrm{L}$, more than three-fold higher than that of domestic sewage, it involved a totally different character in terms of COD fractionation, being predominantly soluble, whereas in domestic sewage, particulate COD accounts for more than $60 \%$ of the total COD $[25,43,59]$. Accordingly, soluble total biodegradable COD was taken to be $100 \mathrm{mg} / \mathrm{L}$ (representing 24\% of the total COD) for domestic sewage, whereas it was $740 \mathrm{mg} / \mathrm{L}$ ( $55 \%$ of the total COD content) for the textile effluents. This significant difference in the COD fractionation of the two wastewaters was the main reason for their selection, to better emphasize and reflect the merit of MASM and the performance of SFMAS.

In this context, the proposed model, MASM, tested the performance of the MAS operation, while a parallel CAS system was evaluated by means of ASM1, modified for endogenous decay. The assessments of both systems were essentially focused on the impacts on two key parameters, i.e., the sludge age, $\theta_{X}(\mathrm{SRT})$, and the hydraulic retention time, $\theta_{\mathrm{H}}(\mathrm{HRT})$. They were carried out for a set of different operating conditions: (i) In the first step, modeling involved different footprints, i.e., different HRT values for the two systems, usually adopted for design, but the same SRT values; this parameter was varied in different runs within the super-fast system operation. (ii) In the second step, models were implemented using the same HRT value, i.e., the same reactor volume and MLSS level (around $5000 \mathrm{mg} / \mathrm{L}$ ) for the two systems. 


\subsection{The Fate of Soluble Hydrolyzable COD}

Wastewater characteristics reflect a clear indication that the soluble hydrolyzable COD fraction, $\mathrm{S}_{\mathrm{H}}$, is the key COD component, affecting and controlling organic carbon removal. In fact, it corresponds to around $50 \%$ of the total soluble COD, $\mathrm{S}_{\mathrm{T}}$, for domestic sewage and the textile wastewater. The merit of the super-fast operation of MAS systems lies in the fact that it emphasizes the major impact of the $\mathrm{S}_{\mathrm{HC}}$ fraction, which accounted for $76 \%$ of the total $\mathrm{S}_{\mathrm{H} 1}$ in domestic sewage and $78 \%$ in textile wastewater. This shows the major shortcoming of the existing activated sludge models (ASMs), as they are not structured to differentiate and depict $\mathrm{S}_{\mathrm{HC}}$ fractions.

\subsubsection{AS Configurations with Different HRT Levels}

In this step, the design principles, and mixed liquor suspended solids' (MLSS) recommendations and restrictions, were observed for both the SFAS (super-fast activated sludge process with gravity settling) and SFMAS systems. The SRT adopted for evaluation was changed for each different run to a value between 0.3 and $2.0 \mathrm{~d}$. First, models ASM1 and MASM were implemented with MLSS levels of $4000-4400 \mathrm{mg} / \mathrm{L}$ and 10,250-10,500 mg/L for SFAS and SFMAS, respectively, yielding an HRT span of $0.7-3.2 \mathrm{~h}$ for SFAS and $0.2-1.4 \mathrm{~h}$ for SFMAS; thus, there were two sets of different reactor volumes and footprints.

Modeling results for achievable $S_{H}$ removals are summarized in Table 4, which underline a few significant aspects about the behavior of parallel units. First of all, for SFAS, $\mathrm{S}_{\mathrm{H}}$ removal has to be calculated based on the entire influent soluble hydrolyzable $\mathrm{COD}, \mathrm{S}_{\mathrm{H} 1}$; for SFMAS, however, the influent soluble hydrolyzable COD, $\mathrm{S}_{\mathrm{H} 1}$, is broken down into two different components. The $\mathrm{S}_{\mathrm{HC}}$ component is retained in the reactor; the remaining fraction, $\Delta \mathrm{S}_{\mathrm{H}}=\mathrm{S}_{\mathrm{H} 1}-\mathrm{S}_{\mathrm{HC}}$ is hydrolyzed, and the remaining part bypasses the membrane into the effluent, giving the value of the effluent soluble hydrolyzable COD, $\mathrm{S}_{\mathrm{HE}}$. For domestic sewage (i) at HRT values smaller than $1.0 \mathrm{~h}(\mathrm{SRT}<0.5 \mathrm{~d}), \mathrm{S}_{\mathrm{H}}$ simply bypassed the reactor with negligible removal, yet the effluent $S_{\mathrm{HE}}$ of the SFMAS unit could be reduced down to $14 \mathrm{mg} / \mathrm{L}$, simply by entrapping and capturing the remaining $\mathrm{S}_{\mathrm{HC}}$ portion in the reactor. (ii) At SRT values between 1.0-2.0 h, SFMAS preformed far better, with significantly lower $\mathrm{S}_{\mathrm{HE}}$ values below $10 \mathrm{mg} / \mathrm{L}$; this was also related to the captured $\mathrm{S}_{\mathrm{HC1}}$ fraction, which is accounted for in the proposed model, MASM. For example, at an SRT of $1.0 \mathrm{~d}, \mathrm{~S}_{\mathrm{HE}}$ values of $15 \mathrm{mg} / \mathrm{L}$ and $8.0 \mathrm{mg} / \mathrm{L}$ may be compared for SFAS and SFMAS, respectively. (iii) $S_{H}$ removal rates remained consistently lower for SFMAS, even though it was evaluated for the influent $S_{H}$ fraction that escaped entrapment by the membrane due the controlling impact of HRT and significantly lower SRT levels adopted in the modelling of SFMAS. (vi) The modeling results indicated that the SRT level of $2.0 \mathrm{~d}$ could be regarded as a breaking point, which secures almost complete $S_{H}$ removal, regardless of the type of AS system.

The textile wastewater was much stronger with a total $\mathrm{S}_{\mathrm{H} 1}$ concentration of $460 \mathrm{mg} / \mathrm{L}-$ approximately four times higher than its counterpart in domestic sewage. Therefore, the discrepancy of $S_{H}$ removals between the two systems was far more enhanced and visible, clearly underlining the decisive role of the captured $\mathrm{S}_{\mathrm{HC} 1}$ fraction in the better performance of the SFMAS system. Similarly, hydrolysis of $\mathrm{S}_{\mathrm{H}}$ was practically negligible at an SRT of $0.3 \mathrm{~d}$, and only partial at an SRT of $0.5 \mathrm{~d}$. At SRT values between 1.0 and $2.0 \mathrm{~d}$, the effluent $\mathrm{S}_{\mathrm{HE}}$ values of $23-33 \mathrm{mg} / \mathrm{L}$ associated with the SFMAS units were significantly lower than the $42-95 \mathrm{mg} / \mathrm{L}$ range obtained with SFAS systems. However, $\mathrm{S}_{\mathrm{H}}$ removal rates remained, again, consistently lower for SFMAS units. 
Table 4. $\mathrm{S}_{\mathrm{H}}$ removal in SFAS and SFMAS systems operated for different footprints (different HRTs).

\begin{tabular}{|c|c|c|c|c|c|c|c|c|c|}
\hline \multirow{2}{*}{ Wastewaters } & \multicolumn{5}{|c|}{ AS with Gravity Settling } & \multicolumn{4}{|c|}{ AS with Membrane } \\
\hline & SRT (d) & HRT (h) & $\mathrm{S}_{\mathrm{HE}}(\mathrm{mg} / \mathrm{L})$ & $S_{H}$ Removal (\%) & MLSS & HRT (h) & $\mathrm{S}_{\mathrm{HE}}(\mathrm{mg} / \mathrm{L})$ & $S_{H}$ Removal (\%) & MLSS \\
\hline \multicolumn{10}{|l|}{ Domestic } \\
\hline & 0.3 & 0.7 & 60 & 3 & 4.400 & 0.2 & 14 & 6 & 10.200 \\
\hline & 0.5 & 1.1 & 30 & 52 & 4.250 & 0.4 & 10 & 33 & 10.250 \\
\hline & 1 & 2.2 & 15 & 76 & 4.190 & 0.7 & 8 & 53 & 10.100 \\
\hline & 1.5 & 2.5 & 13 & 79 & 4.050 & 0.9 & 7 & 54 & 10.100 \\
\hline & 2 & 3.2 & 9 & 85 & 4.000 & 1.4 & 5.5 & 67 & 10.050 \\
\hline \multicolumn{10}{|l|}{ Textile } \\
\hline & 0.5 & 2.2 & 212 & $\begin{array}{l}0.0 \\
54\end{array}$ & 4.300 & 0.85 & 54 & $\begin{array}{c}1 \\
46\end{array}$ & $\begin{array}{l}10.250 \\
10.240\end{array}$ \\
\hline & 1 & 3.6 & 95 & 79 & 4.300 & 1.8 & 33 & 67 & 10.100 \\
\hline & 1.5 & 5 & 56 & 88 & 4.150 & 2.2 & 29 & 71 & 10.000 \\
\hline & 2 & 5.8 & 42 & 91 & 4.100 & 2.7 & 23 & 77 & 10.030 \\
\hline
\end{tabular}

\subsubsection{AS Configurations Adjusted to the Same HRT Levels}

In the second step, HRT levels of parallel systems were fixed at the same values by adjusting the MLSS to around 4.500-5.500 mg/L in both SFAS and SFMAS units. This adjustment induced a slight HRT decrease for SFAS units and a corresponding HRT increase for SFMAS units in the range of $0.4-2.9 \mathrm{~h}$ for domestic sewage, and $1.2-5.0 \mathrm{~h}$ for textile wastewater. SRT levels were maintained at $0.3-2.0 \mathrm{~d}$, which characterizes SFMAS operation.

Model evaluations summarized in Table 5 basically confirm the earlier results: no matter how the HRT was selected, the performances of the SFMAS systems were far superior, with effluent $S_{\mathrm{HE}}$ levels below $10 \mathrm{mg} / \mathrm{L}$ at SRT values higher than $0.5 \mathrm{~d}$ coupled with higher $\mathrm{S}_{\mathrm{H}}$ removal rates.

Table 5. $\mathrm{S}_{\mathrm{H}}$ removal in SFAS and SFMAS systems operated at the same HRT values.

\begin{tabular}{|c|c|c|c|c|c|c|c|c|}
\hline \multirow{2}{*}{ Wastewaters } & \multirow[b]{2}{*}{ SRT (d) } & \multirow[b]{2}{*}{ HRT (h) } & \multicolumn{3}{|c|}{ AS with Gravity Settling } & \multicolumn{3}{|c|}{ AS with Membrane } \\
\hline & & & $\mathrm{S}_{\mathrm{HE}}(\mathrm{mg} / \mathrm{L})$ & $S_{H}$ Removal (\%) & MLSS & $\mathrm{S}_{\mathrm{HE}}(\mathrm{mg} / \mathrm{L})$ & $S_{H}$ Removal (\%) & MLSS \\
\hline \multicolumn{9}{|l|}{ Domestic } \\
\hline & 0.3 & 0,4 & 60 & 3 & 4.800 & 14 & 7 & 5.500 \\
\hline & 0.5 & 0.72 & 40 & 35 & 4.660 & 9 & 42 & 5.440 \\
\hline & 1 & 1.44 & 25 & 61 & 4.520 & 6 & 60 & 5.210 \\
\hline & 1.5 & 2.2 & 18 & 74 & 4.150 & 4.6 & 73 & 5.100 \\
\hline & 2 & 2.9 & 13 & 81 & 4.160 & 3.4 & 77 & 5.150 \\
\hline \multicolumn{8}{|l|}{ Textile } & 5.550 \\
\hline & 0.5 & 2.4 & 197 & 57 & 5.165 & 27 & 73 & 5.470 \\
\hline & 1 & 3.6 & 95 & 79 & 5.020 & 18 & 82 & 5.400 \\
\hline & 1.5 & 4.3 & 68 & 85 & 5.000 & 15 & 85 & 5.210 \\
\hline & 2 & 5 & 50 & 89 & 4.980 & 12 & 88 & 5.100 \\
\hline
\end{tabular}

Modeling of textile effluents highlighted the superior features of the SFMAS system: It showed that SFMAS was applicable to strong wastewaters, bringing the $460 \mathrm{mg} / \mathrm{L}$ of $\mathrm{S}_{\mathrm{H} 1}$ contained in the textile effluent down to $18 \mathrm{mg} / \mathrm{L}$ at SRT of $1.0 \mathrm{~d}$, and to $12 \mathrm{mg} / \mathrm{L}$ at SRT of $2.0 \mathrm{~d}$ compared to 95 and $50 \mathrm{mg} / \mathrm{L}$ in the corresponding AS units with gravity settling. This performance difference was mainly due to the effective filtration size created by the membrane module, which entrapped and captured the $\mathrm{S}_{\mathrm{HC}}$ fraction.

\subsubsection{The Impact of $\mathrm{HRT}$ on $\mathrm{S}_{\mathrm{H}}$ Removal}

Model evaluation was further extended to better visualize the impact of HRT on achievable $S_{H}$ removal using the same parallel reactors, again. For this purpose, HRT was increased stepwise from 1.0 to $4.0 \mathrm{~h}$ for all system operations at different SRT levels. The results plotted in Figures 3 and 4 provide a clear indication that effluent quality in terms of $\mathrm{S}_{\mathrm{HE}}$ significantly improved with higher HRT levels. 


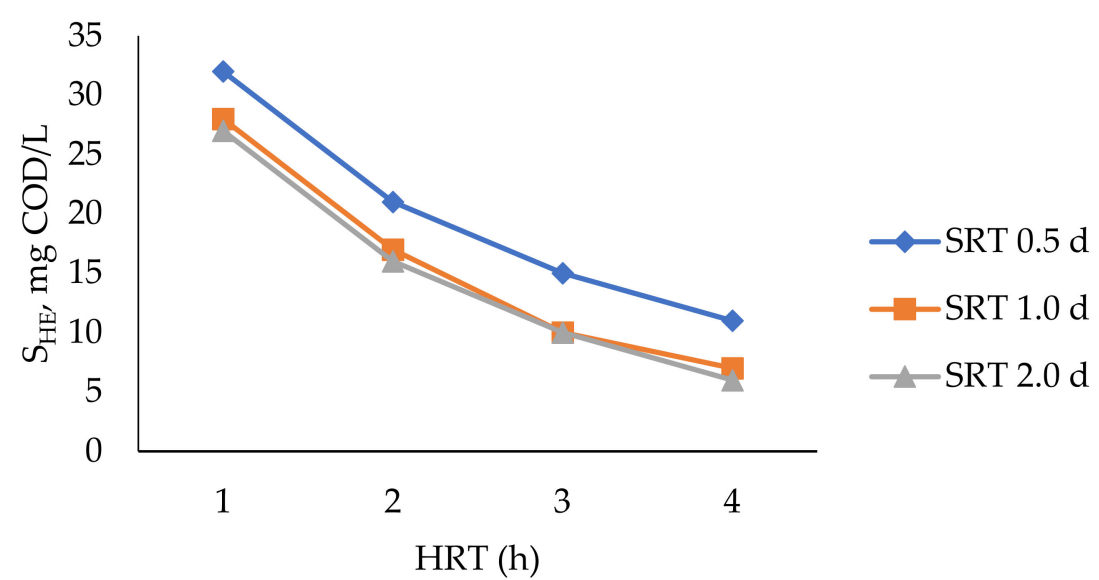

Figure 3. The impact of HRT on $\mathrm{S}_{\mathrm{H}}$ removal from domestic sewage using SFAS.

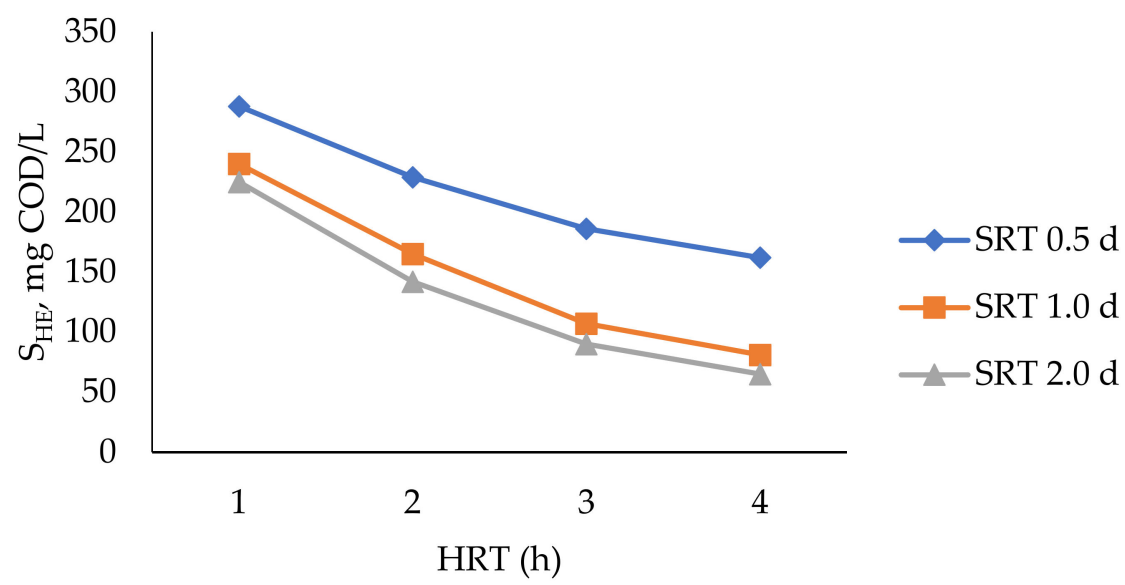

(a)

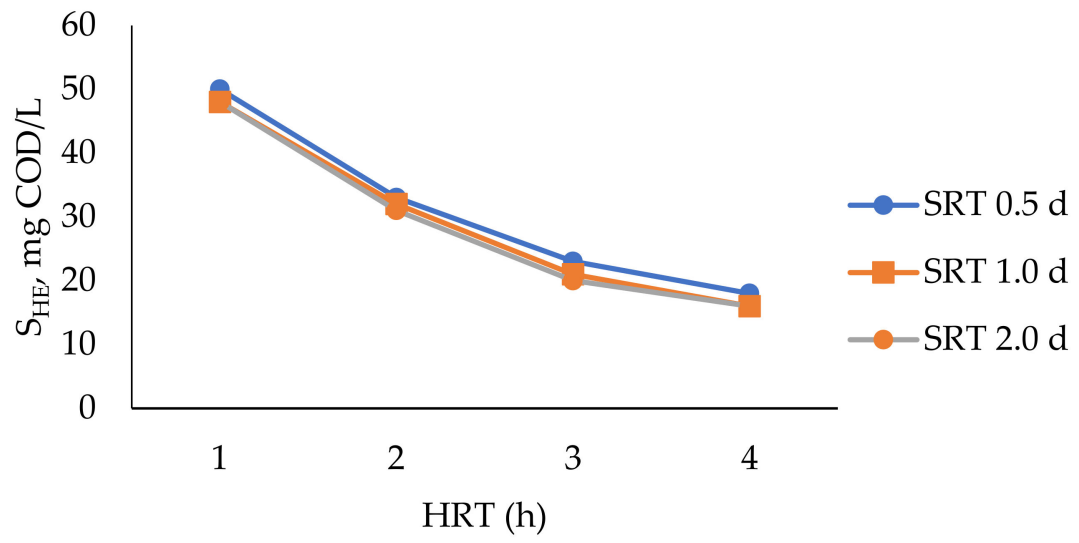

(b)

Figure 4. The impact of HRT on $\mathrm{S}_{\mathrm{H}}$ removal from textile wastewater using (a) SFAS or (b) SFMAS.

For domestic wastewater, while the performance of SFMAS was superb, always producing $\mathrm{S}_{\mathrm{HE}}$ levels below $10 \mathrm{mg} / \mathrm{L}$, the one for SFAS significantly recovered, gradually, as the HRT increased: for example, for SFAS operated at an SRT of $1.0 \mathrm{~d}, \mathrm{~S}_{\mathrm{HE}}$ decreased from $28 \mathrm{mg} / \mathrm{L}$ at HRT of $1.0 \mathrm{~h}$, to $7.0 \mathrm{mg} / \mathrm{L}$ when the HRT was raised to $4.3 \mathrm{~h}$ (Figure 3). Similar observations were confirmed at a larger scale for the textile wastewater: All $\mathrm{S}_{\mathrm{HE}}$ values defined for each of the SRT level associated with superfast AS operation exhibited a substantial decrease when the HRT was gradually increased from 1.0 to $4.0 \mathrm{~h}$. At an SRT 
of $1.0 \mathrm{~d}$, for example, the $\mathrm{S}_{\mathrm{HE}}$ determined as $240 \mathrm{mg} / \mathrm{L}$ showed stepwise decreases to 165 , 107 and $81 \mathrm{mg} / \mathrm{L}$, when the corresponding HRT levels were raised to 2, 3.2 and $4.3 \mathrm{~h}$, respectively (Figure 4).

Furthermore, it should also be noted that the $\mathrm{S}_{\mathrm{HE}}$ levels and $\mathrm{S}_{\mathrm{H}}$ removal rates associated with SFMAS operation were substantially better than their counterparts in SFAS systems. These observations are important for confirming the merits of the new MASM model proposed in the study, mainly because the recognition of the $\mathrm{S}_{\mathrm{H}}$ fraction captured in the biological reactor as a model component clearly reveals the shortcomings of the conventional ASM approach in correctly evaluating and predicting the performance of high-rate AS systems coupled with membrane filtration.

\subsection{Effluent Quality}

The second part of the evaluation was devoted to the assessment of effluent quality in terms of all COD fractions involved and a performance comparison of super-fast activated sludge operation with and without membrane filtration. The modelling results were plotted for SFAS and SFMAS systems in Figure 5 for domestic sewage and Figure 6 for textile wastewater when the corresponding systems were adjusted to the same HRT levels.

The data displayed in these Figures are quite significant in the sense that they indicate the relative contributions of different $\mathrm{COD}$ fractions to the effluent quality under the conditions that define super-fast activated sludge configurations; together with $\mathrm{S}_{\mathrm{H}}$, they also reflect the major role of the influent soluble inert COD, $\mathrm{S}_{\mathrm{I} 1}$, on the influent total soluble COD. Industrial wastewaters are usually characterized by high $\mathrm{S}_{\mathrm{I} 1}$ levels that alone threaten the effluent limitations. In fact, the $S_{\mathrm{I} 1}$ value given in Table 2 was $225 \mathrm{mg} / \mathrm{L}$ for the selected textile wastewater, compared to only $18 \mathrm{mg} / \mathrm{L}$ for domestic sewage. Therefore, it is crucially important to account for the captured fraction of $\mathrm{S}_{\mathrm{I} 1}$ in SFMAS systems to provide an accurate evaluation of system behavior and effluent quality. This underlines the major shortcoming of the ASM models for evaluating and predicting the performances of activated sludge systems with membrane separation.

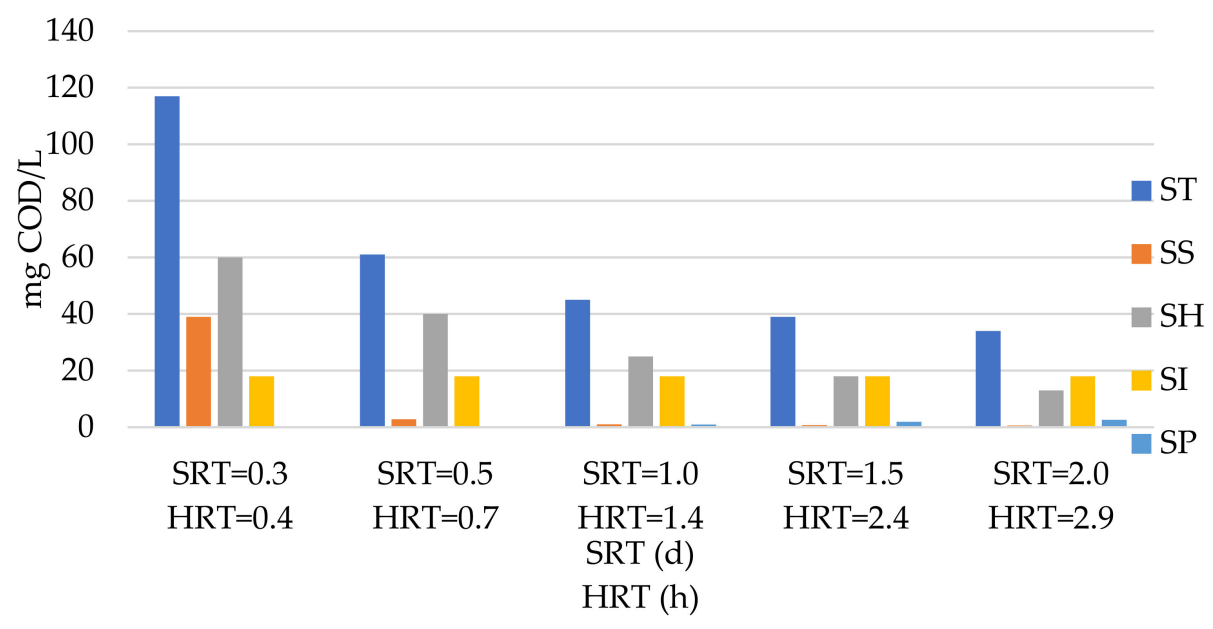

(a)

Figure 5. Cont. 


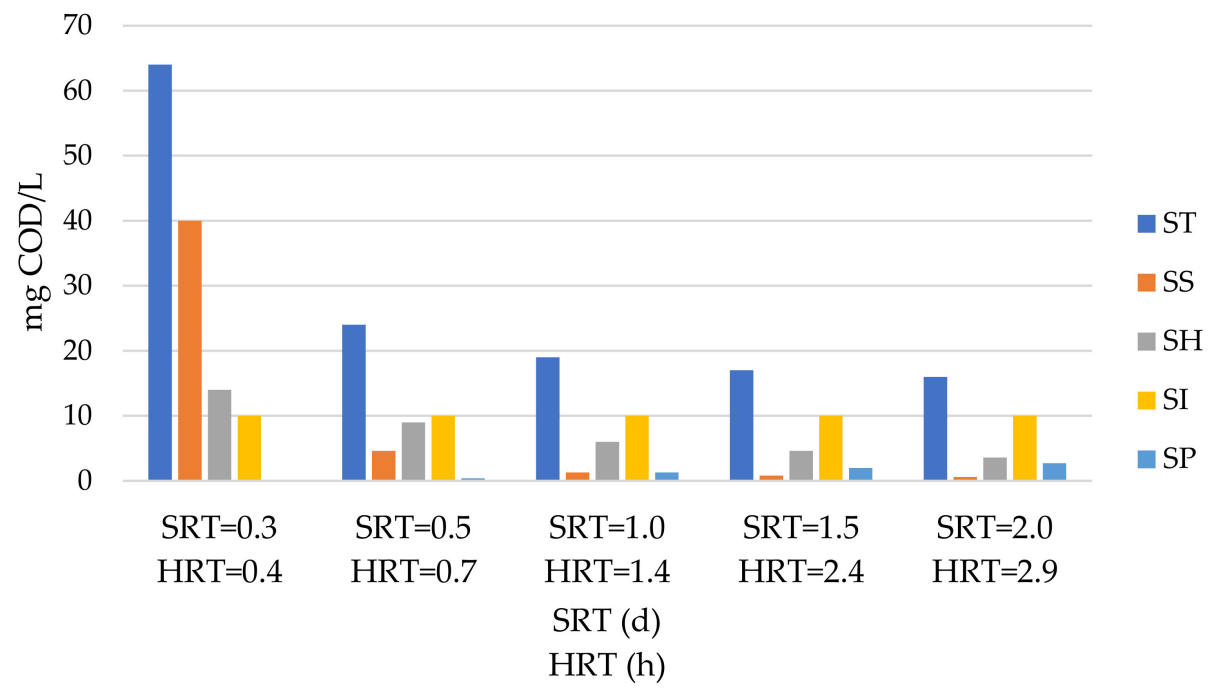

(b)

Figure 5. Effluent COD fractionation of domestic sewage for (a) SFAS and (b) SFMAS operated at the same HRT levels.

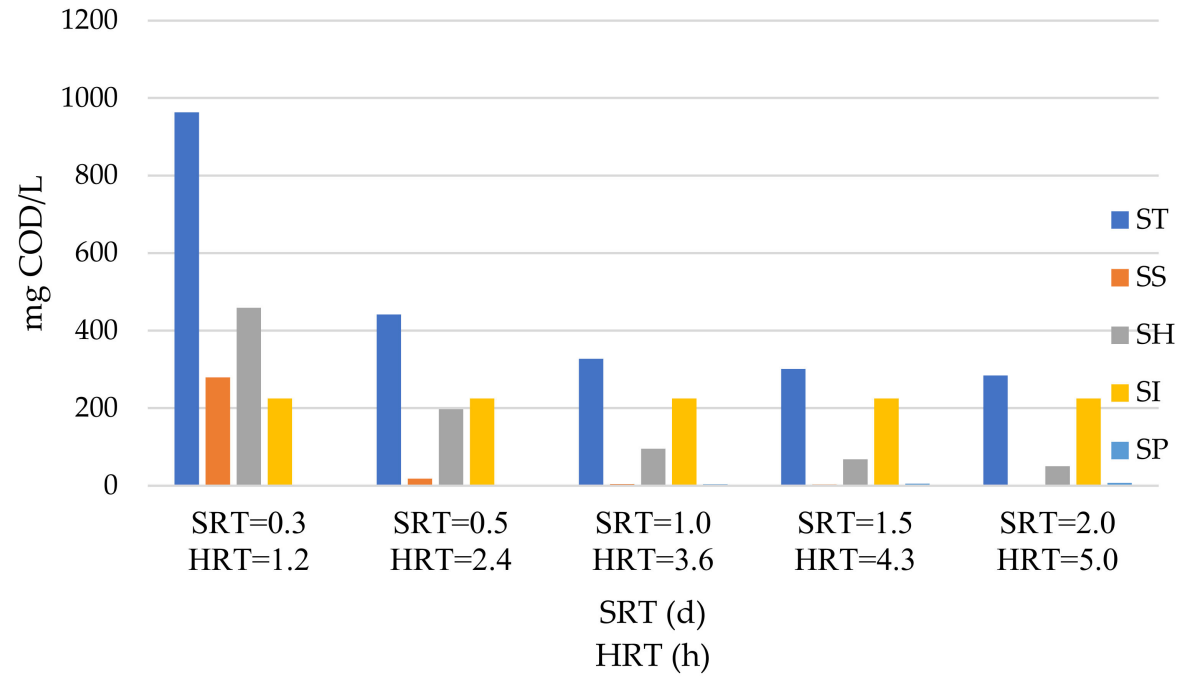

(a)

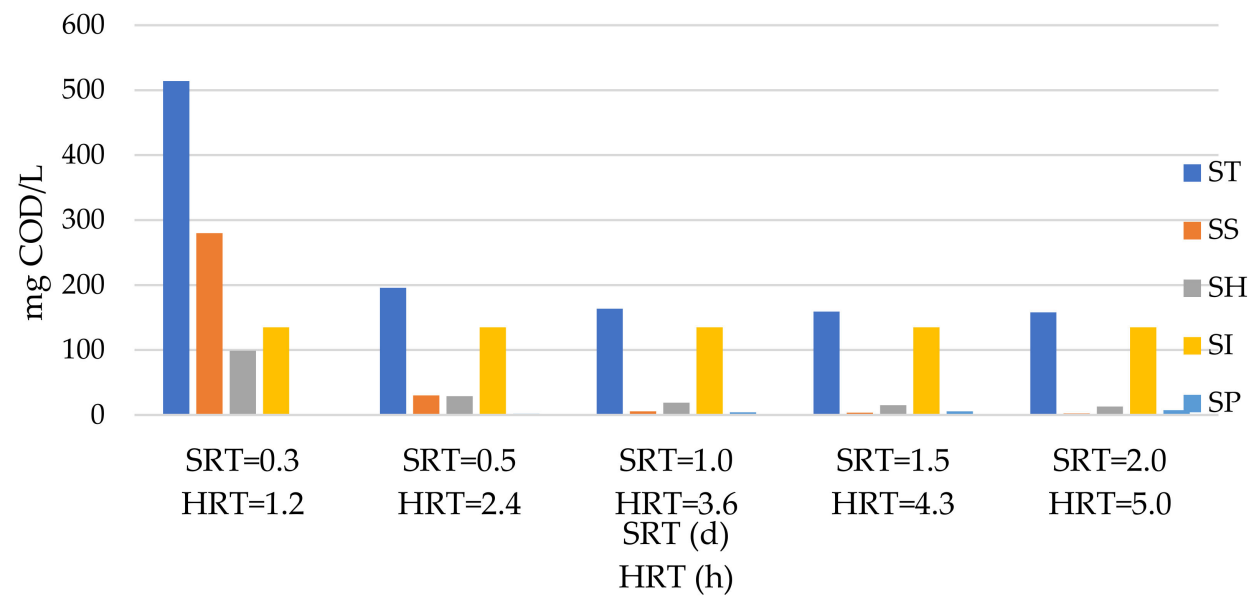

(b)

Figure 6. Effluent COD fractionation of textile wastewater for (a) SFAS and (b) SFMAS operated at the same HRT levels. 
The previous section showed that $\mathrm{S}_{\mathrm{H}}$ removal could be optimized by assigning HRT values higher than the design levels associated with smaller footprints, i.e., reactor volumes, due to the related mass balance indicating the impact of HRT on $\mathrm{S}_{\mathrm{H}}$ removal. Therefore, the effluent quality evaluations will be restricted to cases with the same HRT selections for parallel systems. The distribution of effluent COD fractions displayed in Figure 4 revealed significant observations that need to be further emphasized: First of all, they showed that SRT values below $0.5 \mathrm{~d}$ could not sustain conditions, which would allow the utilization of the readily biodegradable $\mathrm{COD}, \mathrm{S}_{\mathrm{S}}$, for microbial growth; this is quite significant in the sense that the activated sludge configurations could no longer be qualified as biological systems under selected conditions of operation. Complete depletion of $\mathrm{S}_{\mathrm{S}}$ could be secured in parallel units at SRT levels higher than $0.5 \mathrm{~d}$. In the SRT range between 0.5 and $2.0 \mathrm{~d}$, the effluent total COD of the SFMAS units remained below $20 \mathrm{mg} / \mathrm{L}$, half the level that could be achieved with SFAS, due to the capturing of larger particles in $\mathrm{S}_{\mathrm{H}}$ and $\mathrm{S}_{\mathrm{I}}$.

The positive attributes of the SFMAS configuration could better be visualized for the textile wastewater characterized by far higher $\mathrm{S}_{\mathrm{H} 1}$ and $\mathrm{S}_{\mathrm{I} 1}$ values of 460 and $225 \mathrm{mg} / \mathrm{L}$, respectively, as compared with domestic sewage. To start with, process modeling showed that it was possible to hold the effluent COD down to the vicinity of $150 \mathrm{mg} / \mathrm{L}$, despite significant leakage of soluble inert COD into the effluent COD. This clearly confirmed the suitability of the membrane activated sludge process operated at extremely high rates to strong industrial wastewaters and domestic sewage. The data displayed in Figure 6 showed that the discrepancy between the effluent quality of SFAS and SFMAS significantly increased as the relative magnitude of $S_{\mathrm{HE}}$ with respect to the effluent inert COD became more pronounced. The COD difference computed as $126 \mathrm{mg} / \mathrm{L}$ at SRT of $2.0 \mathrm{~d}$ escalated up to $167 \mathrm{mg} / \mathrm{L}$ when the SRT level was reduced to $1.0 \mathrm{~d}$.

Furthermore, activated systems with gravity settling also suffer from biomass escape from the settler, incorporating an additional particulate COD load into the effluent. In a review on the performances of such systems, it was reported that the effluent particulate COD fluctuated between 100-200 mg/L when the SRT selected for operation was below $1.0 \mathrm{~d}[60]$.

\subsection{Evaluation of Results}

Before the evaluation of simulation results, a brief overview on modelling may be useful. The concept of COD fractionation was introduced in ASM1 to assess fractions with different biokinetic properties. This assessment mainly relied on respirometry as an intrinsic character of the wastewater. The only size implication was the distinction of two hydrolyzable COD fractions. The filtration size of $450 \mathrm{~nm}$ used for the assessment of biomass was selected for simplicity and convenience. Accordingly, gravity settling applied this size barrier for "particulate" COD components that would be kept in the reactor along with the biomass. Thus, the time variable, which would determine the fate of these components-i.e., biodegradation/accumulation — became SRT, and the remaining components were controlled by HRT, based on respective mass-balance relationships. When membrane filtration replaced gravity settling in MBRs, this size barrier was moved down to a much lower size barrier, which also kept higher-size portions of "soluble" COD fractions in this reactor. This obviously inflicts significant changes in the number and fates of the components, which is reflected in system efficiency. This, this new size barrier requires a new model structure and new mass-balance relationships, since the traditional ASM structure cannot account for these changes.

Activated sludge models are structured to provide simplified numerical accounts of the biochemical interactions between substrate and microbial culture. In the last three decades, they displayed a remarkable evolution and improvement on the basis of key experimental observations. Substrate storage of internal polymers such as glycogen and polyhyroxyalkanoate (PHA) was a striking example. Observations that substrate could be diverted from microbial growth into intracellular polymers have formed the basis for the ASM3 [19], and later, for its refined version, ASMGS, i.e., an activated sludge model for simultaneous growth and 
storage [20,61]. In both cases the intracellular polymer was recognized as a new model component together with an appropriate storage mechanism. In this study, the fact that MBR operations always resulted in a soluble COD level in the reactor appreciably higher than the permeate COD, was the decisive observation indicating the role of a different size threshold of the membrane, which rejects and recycles a portion of the COD in the reactor. Accordingly, the proposed MAS model was structured with captured COD fractions as model components and a modified mass balance for related processes.

Modeling results summarized in the preceding section should be interpreted in two different ways. The first one, adopted in the results section, offers a comparative evaluation of two different activated sludge schemes, one with gravity separation and the other with membrane filtration of the treated effluent. This was a simplistic but useful approach emphasizing the merit of the membrane activated sludge operated at extremely low SRT levels. The second, and a more appropriate one, is to conceive of a single membrane activated sludge configuration, where the fate of COD fractions and system performance are evaluated by means of two different models, ASM1 and the proposed MASM. This approach will essentially provide the answer to the question: "Why is a new model needed for activated sludge systems with membrane separation?"

Existing activated sludge models (ASMs) rely on a single size threshold, $450 \mathrm{~nm}$, which basically differentiates COD fractions that would be kept in the reactor, i.e., particulate components, from all soluble COD fractions remaining after biodegradation, which will leave the system through the effluent stream. This interpretation of soluble COD involves a wide particle size range for the distribution of COD fractions, such as soluble hydrolyzable $\mathrm{COD}, \mathrm{S}_{\mathrm{H}}$, and soluble inert $\mathrm{COD}, \mathrm{S}_{\mathrm{I}}$. This concept, which essentially defines the structure of ASMs, is no longer valid and applicable for membrane filtration, which drastically reduces the $450 \mathrm{~nm}$ size threshold down to the effective membrane filtration size. This way, fractions of $S_{\mathrm{H}}$ and $S_{\mathrm{I}}$ will be entrapped and controlled by the sludge age of the system. Consequently, the membrane activated sludge systems can only be properly evaluated by a new model structured for modified COD fractionation with related mass balance implications. This is the basic novelty of the proposed model, MASM, which also underlines the shortcomings of the existing ASMs when applied to MAS systems.

The modeling results also provided conclusive information on the suitability and limitations of SFMAS in terms of achievable COD removal performance and applicable SRT levels. While operation at extremely high rates was originally conceived of and tested for the case of domestic sewage, the model was also quite effective for the treatment of strong industrial wastewaters, such as tested textile effluent. It appears that an SRT level of $2.0 \mathrm{~d}$ could be accepted as the break-point threshold, i.e., a lower limit, for effective removal of biodegradable COD. This SRT level provided almost complete $\mathrm{S}_{\mathrm{H}}$ removal $(<5 \mathrm{mg} / \mathrm{L})$ for domestic sewage and lowered the influent $S_{\mathrm{H} 1}$ value of $460 \mathrm{mg} / \mathrm{L}$ down to $13 \mathrm{mg} / \mathrm{L}$ for the textile effluent, to say nothing of the entrapment and capturing of a significant fraction of the influent soluble inert COD, $\mathrm{S}_{\mathrm{I} 1}$.

In recent years, it became quite fashionable to test and promote activated sludge systems with gravity settling operated at extremely high-rate conditions (HiCAS) at SRT values lower than $0.5 \mathrm{~d}$, presumably for energy recovery. Experimental results were reported for HiCAS operation in an SRT range of 0.1-0.5 d with municipal wastewater [62]; at an SRT of $0.41 \mathrm{~d}$ with a synthetic substrate mixture [63]; at SRTs of 0.24 and $0.5 \mathrm{~d}$ with synthetic substrate mixtures [64]; and at SRTs 0.2 and $0.3 \mathrm{~d}$ with chemically enhanced primary treatment effluent [65]. However, the modeling results of this study delivered decisive proof that with the kinetic information so far derived for domestic sewage and textile effluents, microbial growth could not be sustained, mainly because no substrate utilization could take place during the very short retention time-controlled by the selected SRT_ - of biomass in the aerated reactor. Therefore, the results clearly suggested that reactors operated at an SRT threshold below $0.5 \mathrm{~d}$ could not be considered as biological systems; they would merely serve as holding tanks. 
Furthermore, the mass-balance expressions related to the model structure clearly identified the decisive role of the selected HRT in the level of achievable $S_{H}$ removal. While a small footprint is usually recognized as a significant asset for SFMAS systems, a compromise should be considered between better performance and smaller reactor volume.

\section{Conclusions}

Existing activated models (ASMs) are inherently incapable of reflecting the influences of membrane filtration on the components' fates and biochemical reactions in the membrane activated sludge process. The structure of the novel MASM was based on the effective filtration size imposed by the membrane module, which entraps larger particles. Hence, the novel model defined modified COD fractionation that accounts for the captured COD fractions as additional model components and utilizes related mass-balance relationships. This way, it was equipped to yield an accurate mechanistic description of microbial reactions taking place in MAS systems.

The calibration of the existing ASM models requires experimented data generally derived from respirometry. For the novel model, MASM, describing the impact of membrane filtration of the behavior of activated sludge system's calibration can only be completed with the support of PSD analysis. Thus, particle size distribution analysis was introduced into MASM, which is a new and indispensable experimental tool. It was recommended as an integral complement of respirometry, for establishing size-biodegradation relationships of different COD fractions.

The ability of the super-fast membrane activated sludge method to achieve better effluent quality for the treatment of domestic sewage and textile wastewater could be accurately interpreted by MASM in terms of captured fractions of soluble hydrolyzable COD and soluble inert COD.

Author Contributions: All authors participated and contributed to the design of the paper. Conceptualization, supervision and writing-original draft preparation, D.O.; methodology and software, G.I.; validation, formal analysis and visualization, A.B.Y.; investigation and data curation, B.S. and R.M.; investigation, project administration and writing-review and editing, S.S. All authors have read and agreed to the published version of the manuscript.

Funding: This research received no external funding.

Institutional Review Board Statement: Not applicable.

Informed Consent Statement: Not applicable.

Conflicts of Interest: The authors declare no conflict of interest.

\section{References}

1. Orhon, D.; Sözen, S. Reshaping the activated sludge process: Has the time come or passed? J. Chem. Technol. Biotechnol. 2020, 95, 1632-1639. [CrossRef]

2. Orhon, D. Evolution of the activated sludge process: The first 50 years. J. Chem. Technol. Biotechnol. 2015, 90, 608-640. [CrossRef]

3. Barwal, A.; Chaudhary, R. To study the performance of biocarriers in moving bed biofilm reactor (MBBR) technology and kinetics of biofilm for retrofitting the existing aerobic treatment systems: A review. Rev. Environ. Sci. Biotechnol. 2014, 13, 285-299. [CrossRef]

4. Tian, J.Y.; Liang, H.; Li, X.; You, S.J.; Tian, S.; Li, G.B. Membrane coagulation bioreactor (MCBR) for drinking water treatment. Water Res. 2008, 42, 3910-3920. [CrossRef] [PubMed]

5. Tian, J.Y.; Liang, H.; Yang, Y.L.; Tian, S.; Li, G.B. Membrane adsorption bioreactor (MABR) for treating slightly polluted surface water supplies: As compared to membrane bioreactor (MBR). J. Membr. Sci. 2008, 325, 262-270. [CrossRef]

6. Chae, S.R.; Shin, H.S. Characteristics of simultaneous organic and nutrient removal in a pilot-scale vertical submerged membrane bioreactor (VSMBR) treating municipal wastewater at various temperatures. Process Biochem. 2007, 42, 193-198. [CrossRef]

7. Wu, G.; Guan, Y.; Zhan, X. Effect of salinity on the activity, settling and microbial community of activated sludge in sequencing batch reactors treating synthetic saline wastewater. Water Sci. Technol. 2008, 58, 351-358. [CrossRef] [PubMed]

8. Lin, H.; Peng, W.; Zhang, M.; Chen, J.; Hong, H.; Zhang, Y. A review on anaerobic membrane bioreactors: Applications, membrane fouling and future perspectives. Desalination 2013, 314, 169-188. [CrossRef]

9. Crawford, G.; Thompson, D.; Lozier, J.; Daigger, G.; Fleischer, E. Membrane bioreactors-a designer's perspective. Proc. Water Environ. Fed. 2000, 2000, 311-319. [CrossRef] 
10. Sarioglu, M.; Insel, G.; Artan, N.; Orhon, D. Model evaluation of simultaneous nitrification and denitrification in a membrane bioreactor operated without an anoxic reactor. J. Membr. Sci. 2009, 337, 17-27. [CrossRef]

11. Insel, G.; Hocaoğlu, S.M.; Cokgor, E.U.; Orhon, D. Modelling the effect of biomass induced oxygen transfer limitations on the nitrogen removal performance of membrane bioreactor. J. Membr. Sci. 2011, 368, 54-63. [CrossRef]

12. Sawyer, H.A. Design of concrete frames for two failure stages. Spec. Public 1965, 12, 405-437. [CrossRef]

13. Ng, H.Y.; Hermanowicz, S.W. Membrane bioreactor operation at short solids retention times: Performance and biomass characteristics. Water Res. 2005, 39, 981-992. [CrossRef] [PubMed]

14. Duan, L.; Moreno-Andrade, I.; Huang, C.L.; Xia, S.; Hermanowicz, S.W. Effects of short solids retention time on microbial community in a membrane bioreactor. Bioresour. Technol. 2009, 100, 3489-3496. [CrossRef] [PubMed]

15. Başaran, S.T.; Aysel, M.; Kurt, H.; Ergal, I.; Kumru, M.; Akarsubaşı, A.; Sözen, S.; Orhon, D. Removal of readily biodegradable substrate in super fast membrane bioreactor. J. Membr. Sci. 2012, 423, 477-486. [CrossRef]

16. Başaran, S.T.; Aysel, M.; Kurt, H.; Ergal, I.; Akarsubaşı, A.; Yağc1, N.; Doğruel, S.; Çokgör, E.U.; Keskinler, B.; Sözen, S.; et al. Kinetic characterization of acetate utilization and response of microbial population in super fast membrane bioreactor. J. Membr. Sci. 2014, 455, 392-404. [CrossRef]

17. Sözen, S.; Teksoy-Başaran, S.; Ergal, İ.; Karaca, C.; Allı, B.; Razbonyalı, C.; Ubay-Çokgör, E.; Orhon, D. A novel process maximizing energy conservation potential of biological treatment: Super fast membrane bioreactor. J. Membr. Sci. 2018, 545, 337-347. [CrossRef]

18. Ekama, G.A.; Dold, P.L.; Marais, G.V.R. Procedures for determining influent COD fractions and the maximum specific growth rate of heterotrophs in activated sludge systems. Water Sci. Technol. 1986, 18, 91-114. [CrossRef]

19. Henze, M.; Gujer, W.; Mino, T.; van Loosdrecht, M.C. Activated Sludge Models ASM1, ASM2, ASM2d and ASM3; IWA Publishing: London, UK, 2000. [CrossRef]

20. Karahan, Ö.; van Loosdrecht, M.C.M.; Orhon, D. Modification of activated sludge model no. 3 considering direct growth on primary substrate. Water Sci. Technol. 2003, 47, 219-225. [CrossRef]

21. Munz, G.; Gori, R.; Cammilli, L.; Lubello, C. Characterization of tannery wastewater and biomass in a membrane bioreactor using respirometric analysis. Bioresour. Technol. 2008, 99, 8612-8618. [CrossRef]

22. Arias-Navarro, M.; Villen-Guzman, M.; Perez-Recuerda, R.; Rodriguez-Maroto, J.M. The use of respirometry as a tool for the diagnosis of waste water treatment plants. A real case study in Southern Spain. J. Water Process. Eng. 2019, 29, 100791. [CrossRef]

23. Germirli, F.; Orhon, D.; Artan, N. Assessment of the initial inert soluble COD in industrial wastewaters. Water Sci. Technol. 1991, 23, 1077-1086. [CrossRef]

24. Orhon, D.; Karahan, Ö.; Sözen, S. The effect of residual microbial products on the experimental assessment of the particulate inert COD in wastewaters. Water Res. 1999, 33, 3191-3203. [CrossRef]

25. Henze, M. Characterization of wastewater for modelling of activated sludge processes. Water Sci. Technol. 1992, 25, 1-15. [CrossRef]

26. Orhon, D.; Çokgör, E.U.; Sözen, S. Experimental basis for the hydrolysis of slowly biodegradable substrate in different wastewaters. Water Sci. Technol. 1999, 39, 87-95. [CrossRef]

27. Sophonsiri, C.; Morgenroth, E. Chemical composition associated with different particle size fractions in municipal, industrial, and agricultural wastewaters. Chemosphere 2004, 55, 691-703. [CrossRef] [PubMed]

28. Dulekgurgen, E.; Doğruel, S.; Karahan, Ö.; Orhon, D. Size distribution of wastewater COD fractions as an index for biodegradability. Water Res. 2006, 40, 273-282. [CrossRef] [PubMed]

29. Doğruel, S.; Köktuna, M.; Çokgör, E.U.; Sözen, S.; Orhon, D. Particle size distribution based evaluation of biodegradation and treatability for leachate from organic waste. J. Chem. Technol. Biotechnol. 2001, 86, 1364-1373. [CrossRef]

30. Doğruel, S.; Çokgör, E.U.; Ince, O.; Sözen, S.; Orhon, D. Potential of ultrafiltration for organic matter removal in the polymer industry effluent based on particle size distribution analysis. Environ. Sci. Pollut. Res. 2013, 20, 340-350. [CrossRef]

31. Hocaoglu, S.M.; Atasoy, E.; Baban, A.; Orhon, D. Modeling biodegradation characteristics of grey water in membrane bioreactor. J. Membr. Sci. 2013, 429, 139-146. [CrossRef]

32. Karahan, Ö.; Dogruel, S.; Dulekgurgen, E.; Orhon, D. COD fractionation of tannery wastewaters-Particle size distribution, biodegradability and modeling. Water Res. 2008, 42, 1083-1092. [CrossRef] [PubMed]

33. Hocaoglu, S.M.; Orhon, D. Fate of soluble residual organics in membrane bioreactor. J. Membr. Sci. 2010, 364, 65-74. [CrossRef]

34. Doğruel, S. Biodegradation characteristics of high strength municipal wastewater supported by particle size distribution. Desalin. Water Treat. 2012, 45, 11-20. [CrossRef]

35. Shin, H.S.; Kang, S.T. Characteristics and fates of soluble microbial products in ceramic membrane bioreactor at various sludge retention times. Water Res. 2003, 37, 121-127. [CrossRef]

36. Orhon, D.; Artan, N.; Cimşit, Y. The concept of soluble residual product formation in the modelling of activated sludge. Water Sci. Technol. 1989, 21, 339-350. [CrossRef]

37. Duncan, J.B.; Stuckey, D.C. A review of soluble microbial products (SMP) in wastewater treatment systems. Water Res. 1999, 33, 3063-3082. [CrossRef]

38. Güell, C.; Czekaj, P.; Davis, R.H. Microfiltration of protein mixtures and the effects of yeast on membrane fouling. J. Membr. Sci. 1999, 155, 113-122. [CrossRef]

39. Bowen, W.R.; Yousef, H.N.; Calvo, J.I. Dynamic crossflow ultrafiltration of colloids: A deposition probability cake filtration approach. Sep. Purif. Technol. 2001, 24, 297-308. [CrossRef] 
40. Orhon, D.; Artan, N. Modelling of Activated Sludge Systems, Lancaster; Technomic Publishing Co.: Lancaster, PA, USA, 1994. [CrossRef]

41. Wu, J.; Yan, G.; Zhou, G.; Xu, T. Wastewater COD biodegradability fractionated by simple physical-chemical analysis. Chem. Eng. Technol. 2014, 258, 450-459. [CrossRef]

42. Lubello, C.; Caffaz, S.; Gori, R.; Munz, G. A modified activated sludge model to estimate solids production at low and high solids retention time. Water Res. 2009, 43, 4539-4548. [CrossRef]

43. Noyan, K.; Allı, B.; Okutman Taş, D.; Sözen, S.; Orhon, D. Relationship between COD particle size distribution, COD fractionation and biodegradation characteristics in domestic sewage. J. Chem. Technol. Biotechnol. 2017, 92, 2142-2149. [CrossRef]

44. Garrett, M.T.; Sawyer, C.N. Kinetics of removal of soluble BOD by activated sludge. Purdue Univ. Eng. Bull. 1952, 36, 51-77.

45. Kappeler, J.; Gujer, W. Estimation of kinetic parameters of heterotrophic biomass under aerobic conditions and characterization of wastewater for activated sludge modelling. Water Sci. Technol. 1992, 25, 125-139. [CrossRef]

46. Orhon, D.; Soybay, S.; Tünay, O.; Artan, N. The effect of reactor hydraulics on the performance of activated sludge systems-I. The traditional modelling approach. Water Res. 1989, 23, 1511-1518. [CrossRef]

47. Sumo ${ }^{\circledR}$ Wastewater Process Simulator, Dynamita Process Modeling, Nyons, France, 2018. Available online: http://www. dynamita.com/the-sumo/ (accessed on 14 July 2021).

48. Katipoglu-Yazan, T.; Ubay-Cokgor, E.; Orhon, D. Chronic impact of sulfamethoxazole: How does process kinetics relate to metabolic activity and composition of enriched nitrifying microbial culture? J. Chem. Technol. Biotechnol. 2018, 93, 1722-1732. [CrossRef]

49. Görgün, E.; Insel, G.; Artan, N.; Orhon, D. Model evaluation of temperature dependency for carbon and nitrogen removal in a full-scale activated sludge plant treating leather-tanning wastewater. J. Environ. Sci. Health A 2007, 42, 747-756. [CrossRef] [PubMed]

50. Insel, H.G.; Görgün, E.; Artan, N.; Orhon, D. Model based optimization of nitrogen removal in a full scale activated sludge plant. Environ. Eng. Sci. 2009, 26, 471-480. [CrossRef]

51. Tas, D.O.; Karahan, Ö.; Insel, G.; Övez, S.; Orhon, D.; Spanjers, H. Biodegradability and denitrification potential of settleable chemical oxygen demand in domestic wastewater. Water Environ. Res. 2009, 81, 715-727. [CrossRef] [PubMed]

52. Orhon, D.; Okutman, D.; Insel, G. Characterisation and biodegradation of settleable organic matter for domestic wastewater. Water S.A. 2002, 28, 299-306. [CrossRef]

53. Okutman, D.; Övez, S.; Orhon, D. Hydrolysis of settleable substrate in domestic sewage. Biotechnol. Lett. 2001, 23, 1907-1914. [CrossRef]

54. Murat Hocaoglu, S.; Insel, G.; Ubay Cokgor, E.; Baban, A.; Orhon, D. COD fractionation and biodegradation kinetics of segregated domestic wastewater: Black and grey water fractions. J. Chem. Technol. Biotechnol. 2010, 85, 1241-1249. [CrossRef]

55. Orhon, D.; Çokgör, E.U.; Sözen, S. Dual hydrolysis model of the slowly biodegradable substrate in activated sludge systems. Biotechnol. Tech. 1998, 12, 737-741. [CrossRef]

56. Babuna, F.G.; Orhon, D.; Çokgör, E.U.; Insel, G.; Yaprakli, B. Modelling of activated sludge for textile wastewaters. Water Sci. Technol. 1998, 38, 9-17. [CrossRef]

57. Yildiz, G.; Insel, G.; Cokgor, E.U.; Orhon, D. Biodegradation kinetics of the soluble slowly biodegradable substrate in polyamide carpet finishing wastewater. J. Chem. Technol. Biotechnol. 2008, 83, 34-40. [CrossRef]

58. Doğruel, S.; Orhon, D. Particle size distribution of chemical oxygen demand in industrial effluents: Impact on effective filtration size and modelling of membrane bioreactors. J. Chem. Technol. Biotechnol. 2021. [CrossRef]

59. Orhon, D.; Uslu, O.; Meriç, S.; Salihoglu, I.; Filibeli, A. Wastewater management for Istanbul: Basis for treatment and disposal. Environ. Pollut. 1994, 84, 167-178. [CrossRef]

60. Orhon, D.; Allı, B.; Sözen, S. Which activated sludge configurations qualify for maximizing energy conservation-Why? J. Chem. Technol. Biotechnol. 2019, 94, 556-568. [CrossRef]

61. Karahan, Ö.; van Loosdrecht, M.C.; Orhon, D. Modeling the utilization of starch by activated sludge for simultaneous substrate storage and microbial growth. Biotechnol. Bioeng. 2006, 94, 43-53. [CrossRef] [PubMed]

62. Jimenez, J.; Miller, M.; Bott, C.; Murthy, S.; de Clippeleir, H.; Wett, B. High-rate activated sludge system for carbon managementEvaluation of crucial process mechanisms and design parameters. Water Res. 2015, 87, 476-482. [CrossRef] [PubMed]

63. Meerburg, F.A.; Boon, N.; van Winckel, T.; Vercamer, J.A.; Nopens, I.; Vlaeminck, S.E. Toward energy-neutral wastewater treatment: A high-rate contact stabilization process to maximally recover sewage organics. Bioresour. Technol. 2015, 179, 373-381. [CrossRef]

64. Meerburg, F.A.; Boon, N.; van Winckel, T.; Pauwels, K.T.; Vlaeminck, S.E. Live fast, die young: Optimizing retention times in high-rate contact stabilization for maximal recovery of organics from wastewater. Environ. Sci. Technol. 2016, 50, 9781-9790. [CrossRef] [PubMed]

65. Orhon, D.; Sözen, S.; All, B. Comment on “Bioflocculation management through high-rate contact stabilization: A promising technology to recover organic carbon from low-strength wastewater by Rahman, A., Meerburg, FA, Ravadagundhi, S., Wett, B., Jimenez, J., Bott, C., Al-Omari, A., Riffat, R., Murthy, S. and De Clippeleir, H. [Water Res. 2016, 104, 485-496]". Water Res. 2017, 126, 524-526. [CrossRef] [PubMed] 